\title{
Apple pomace improves gut health in Fisher rats independent of seed content
}

Ravn-Haren, Gitte; Krath, Britta N.; Markowski, Jarosaw; Poulsen, Morten; Hansen, Max; Koodziejczyk, Krzysztof; Kosmala, Monika; Dragsted, Lars 0.

Published in:

Food \& Function

Link to article, DOI:

$10.1039 / \mathrm{c} 7 \mathrm{fo} 01932 \mathrm{~g}$

Publication date:

2018

Document Version

Peer reviewed version

Link back to DTU Orbit

Citation (APA):

Ravn-Haren, G., Krath, B. N., Markowski, J., Poulsen, M., Hansen, M., Koodziejczyk, K., Kosmala, M., \& Dragsted, L. O. (2018). Apple pomace improves gut health in Fisher rats independent of seed content. Food \& Function, 9, 2931-2941. https://doi.org/10.1039/c7fo01932g

\section{General rights}

Copyright and moral rights for the publications made accessible in the public portal are retained by the authors and/or other copyright owners and it is a condition of accessing publications that users recognise and abide by the legal requirements associated with these rights.

- Users may download and print one copy of any publication from the public portal for the purpose of private study or research.

- You may not further distribute the material or use it for any profit-making activity or commercial gain

- You may freely distribute the URL identifying the publication in the public portal

If you believe that this document breaches copyright please contact us providing details, and we will remove access to the work immediately and investigate your claim 


\section{Apple pomace improves gut health in Fisher rats independent of seed content}

Gitte Ravn-Haren $^{1 *}$, Britta N. Krath ${ }^{2}$, Jarosław Markowski ${ }^{3}$, Morten Poulsen ${ }^{1}$, Max Hansen ${ }^{4}$, Krzysztof Kołodziejczyk $^{5}$, Monika Kosmala ${ }^{5}$ and Lars O. Dragsted ${ }^{2}$

${ }^{1}$ Division for Diet, Disease Prevention and Toxicology, National Food Institute, Technical University of Denmark, Kgs. Lyngby, Denmark

${ }^{2}$ Department of Nutrition, Exercise and Sports, University of Copenhagen, Frederiksberg, Denmark

${ }^{3}$ Research Institute of Horticulture, Skierniewice, Poland

${ }^{4}$ Division for Risk Assessment and Nutrition, National Food Institute, Technical University of Denmark, Kgs. Lyngby,

Denmark

${ }^{5}$ Institute of Food Technology and Analysis, Lodz University of Technology, Lodz, Poland

${ }^{*}$ Corresponding author: Gitte Ravn-Haren, Division for Diet, Disease Prevention and Toxicology, National Food Institute, Technical University of Denmark, Kemitorvet, 2800 Kgs. Lyngby. Tel:+45-35887600, email:girh@food.dtu.dk. ORCID ID: 0000-0002-4587-089X 


\begin{abstract}
The mechanism behind the cholesterol lowering effects of apple pomace, a polyphenol- and fibre rich by-product in apple juice production, was investigated. Groups of male F344 rats were fed a control feed or the same feed with $2.1 \%$ or $6.5 \%$ dry apple pomace with or without seeds for 4 weeks. Effects on plasma cholesterol concentrations, excretion of bile acids, expression of genes involved in cholesterol- and bile acid synthesis, and other markers related to gut health were investigated. We found that pomace feeding decreased total-, LDL- and IDL-cholesterol concentrations compared to control. Higher production of SCFA, indicating elevated caecal fermentation, and increased excretion of total- and primary bile acids could explain the observed hypocholesterolemic effects of apple pomace, however, expression of selected genes involved in cholesterol and bile acid biosynthesis (Hmgcr and Cyp7a1) were not affected. We found no hepatotoxic or other effects of apple seeds. Altogether, our results indicate that apple pomace has beneficial effects on gut health, and that the cholesterol-lowering effect is linked to increased production of SCFA and excretion of bile acids. These effects are most likely linked to the fibre and other fruit constituents present in the pomace. Presence of apple seeds seems to impart no toxicity even at $6.5 \%$ pomace in the feed and seeds also had no influence on the biological effect of the pomace. In the future, apple pomace could potentially be used as a bioactive and possibly health promoting food ingredient.
\end{abstract}

Keywords CVD, lipid metabolism, functional food, dietary fibre, apple polyphenols, SCFA 


\section{Introduction}

Several studies report an inverse association between fruit intake and risk of CVD. ${ }^{1-4}$ Apples are among the most frequently eaten fruits in Europe, and apple consumption is inversely related to CVD risk. ${ }^{5-7}$ The health benefits are often ascribed to their content of polyphenols and dietary fibre, which are both reported to normalize undesirable lipid metabolism by decreasing serum cholesterol concentrations in some animal feeding experiments ${ }^{8-14}$ and human intervention studies. ${ }^{15-21}$ Most phenolic compounds are poorly absorbed, however in two studies by Nagasako-Akazome et al., supplementation with apple polyphenols resulted in decreased plasma cholesterol concentrations in mildly hypercholesterolemic subjects. ${ }^{19,20}$ Polyphenols reaching the colon are extensively metabolised by the colonic microbiota, resulting in the production of microbial metabolites, such as low molecular weight aromatic acids that are easily absorbed. ${ }^{22}$ The effective doses used in the two studies by Nagasako-Akazome et al. are far above what is realistic to obtain from a human diet and it is therefore not likely that apple polyphenols are the main responsible compounds for the beneficial effects in studies with whole apples or apple products. It therefore seems more likely that the beneficial effects of apple on plasma cholesterol concentrations are related to their high content of dietary fibre or to a combination effect with polyphenols or other constituents. ${ }^{23-25}$

Several mechanisms have been proposed to explain the cholesterol-lowering effect of dietary fibre. Among these are decreased cholesterol uptake and increased faecal excretion of bile acids, related to the viscous properties of the soluble dietary fibre. ${ }^{26}$ Since bile acids are synthesised from cholesterol in the liver, this increased excretion might result in de novo biosynthesis of both bile acids and cholesterol in the liver. The enzyme $7 \alpha$-hydroxylase encoded by Cyp7a1 catalyses the first and rate-limiting step in the classical/neutral pathway to convert cholesterol into bile acids, ${ }^{27}$ while HMG-CoA reductase, encoded by Hmgcr, is involved in hepatic cholesterol biosynthesis. Gut microbiota has been linked with lipid metabolism by affecting hepatic Cyp7a1 expression and metabolism of bile acids facilitating faecal excretion. ${ }^{28}$ Another proposed mechanism involves short-chain fatty acids (SCFA) produced by the intestinal microbiota during fermentation of the fibre. These fermentation products, which include acetate, propionate and butyrate, are reported to affect lipid metabolism in the liver. ${ }^{29}$ It seems plausible that more than one mechanism might be involved in the hypocholesterolemic effects of apples.

Not all apples are of sufficiently high quality to be sold in the fresh market and they are therefore processed into different apple products, such as apple juices. As a result, large amounts of apple pomace are produced. This wasteproduct is rich in polyphenols and dietary fibres, and might be a promising ingredient in the development of healthy consumer products. 
The purpose of the present study was to investigate effects of apple pomace on caecal fermentation, plasma cholesterol concentrations, bile acid excretion and expression of genes involved in cholesterol metabolism to try to clarify the mechanism behind the previously reported cholesterol-lowering effect of apple pomace. ${ }^{12,14}$ We chose to include both standard pomace and pomace without apple seeds, since seeds are not always removed during processing and might have adverse effects. The low content of cyanohydrins in apple seeds might theoretically pose a health risk if apple pomace including seeds is consumed in large amounts.

\section{Materials and methods}

\section{Animals and housing}

Fifty male F344 rats (4 weeks old) were obtained from Charles River (Sulzfeld, Germany). The animals were housed two by two in standard cages under controlled environmental conditions with temperature at $22 \pm 1{ }^{\circ} \mathrm{C}$, relative humidity at $55 \pm 5 \%$ a 12/12 h light/dark cycle (9:00 a.m.-9:00 p.m), and air exchanged 8-10 times/h. Diets and acidified water (adjusted to $\mathrm{pH} 3.05$ by citric acid to prevent growth of microorganisms) were provided ad libitum. Ethical approval was given by the Danish Animal Experiments Inspectorate (ethics authorization number 2004/561-917 C9) and the experiment was overseen by the National Food Institute's in-house Animal Welfare Committee for animal care and use.

\section{Apple pomaces}

Dried apple pomace (cultivar 'Shampion') was supplied from the Research Institute of Horticulture (Formerly Research Institute of Pomology and Floriculture), Skierniewice, Poland. Both apple pomace preparations derived from fruits harvested the same year. After harvest the apples were stored at normal atmosphere and $+2{ }^{\circ} \mathrm{C}$ to obtain a proper degree of ripening before processing. Apple pomace preparations were obtained by air drying of pomaces from standard apple juice processing technology close to processing in the commercial scale. One batch was air dried without processing and is called standard pomace. A second batch of pomace was washed with potable water to decrease stickiness, dried and then the seeds were removed by sieving, allowing the production of pomace without seeds. Preparations for the experiments were produced by gentle air drying $\left(70^{\circ} \mathrm{C}, 12 \mathrm{~h}\right)$. Both types of pomaces were ground to maximize the uniformity of feeding material.

Dry weight was determined by drying at $70{ }^{\circ} \mathrm{C}$ at 30 mbar vacuum, content of sugars and sorbitol were determined by EN 12630 method. Contents of total dietary fibre, total- and soluble pectin were determined according to the standard 
AOAC Official Method 933.21 and method No. 26 of the International Federation of fruit juice producers (IFU) (www.ifu-fruitjuice.com). The contents of (+)-catechin, (-)-epicatechin, procyanidin B2, caffeoylquinic acid, 4-(pcoumaroyl)-quinic acid, dihydrochalcones and quercetin glycosides were determined by HPLC according to Tsao et al. ${ }^{30}$ while the procyanidins and their degree of polymerisation were determined as reported by Guyot et al. ${ }^{31}$ Contents of ash (NMKL 173:2005), total protein (NMKL 6:2003 modified Kjeldahl), carbohydrate (AOAC 982.14) and fat (ISO 11085:2015) were determined by Eurofins Steins Laboratory A/S (Vejen, Denmark) according to the accredited methods provided in brackets.

\section{Diets and study design}

The rats were randomly assigned to one of 5 groups based on body weight. After one week of adaptation to the purified control diet, the rats were fed either control diet or control diet added $2.1 \%$ standard apple pomace with apple seeds or pomace without apple seeds, or control diet added 6.5\% standard apple pomace with seeds or pomace without apple seeds for 4 weeks (Table 1). Contents of carbohydrates in the purified diets were adjusted according to the amount of apple pomace added. Feed intake was recorded daily and body weight was recorded weekly. After 4 weeks intervention, the rats were sacrificed by decapitation under $\mathrm{CO}_{2} / \mathrm{O}_{2}$ anaesthesia followed by exsanguination. Liver and caecum were weighed and samples from caecum content were taken for analyses of short-chain fatty acids (SCFA) and activities of $\beta$-glucosidase (BGL) and $\beta$-glucuronidase (GUS).

\section{Blood sampling and sample handling}

After decapitation, blood was collected in heparin-coated tubes (Becton Dickinson, Plymouth, UK) and plasma isolated by centrifugation $\left(20 \mathrm{~min}, 2200 \mathrm{x} \mathrm{g}, 4^{\circ} \mathrm{C}\right)$ for analyses of plasma alanine aminotransferase activity (ALAT), ferric reducing ability of plasma (FRAP), Trolox equivalent antioxidant capacity (TEAC) and lipoprotein cholesterol concentrations. Lipoproteins were separated into five fractions by single density gradient ultracentrifugation of plasma for $18 \mathrm{~h}$ at $21^{\circ} \mathrm{C} .{ }^{32}$ Plasma samples were stored at $-80^{\circ} \mathrm{C}$ until analysed, while cholesterol concentrations in lipoprotein fractions were determined immediately after ultracentrifugation. Erythrocytes were lysed by addition of an equal volume of MilliQ water and stored at $-80^{\circ} \mathrm{C}$. One $\mathrm{ml}$ of blood was collected into a PAXgene blood RNA tube for purification of RNA from the white blood cells (Becton Dickinson, Plymouth, UK). For each analysis, all samples were run in a randomised order within the same batch to minimise analytical variation. 


\section{Cholesterol concentrations in lipoprotein fractions and plasma ALAT activity}

Cholesterol concentrations in lipoprotein fractions and plasma ALAT enzyme activity were determined using a commercially available kit from Roche Diagnostics (Mannheim, Germany; catalogue no. A11A01634 and no. 10851132, respectively). Both analyses were determined on a Roche/Hitachi 912 analyser (Roche Diagnostics).

\section{Measurement of pH and analysis of short chain fatty acid (SCFA) composition in caecal samples}

Shortly after the caecum was opened, $\mathrm{pH}$ was measured in the distal end of the caecum. Acetate, propionate, and butyrate in caecal contents were analyzed using capillary electrophoresis and indirect UV detection by a method modified from Westergaard et al. ${ }^{33}$ Briefly, approximately $0.1 \mathrm{~g}$ of caecal contents was diluted 10 times in alkaline buffer (0.1 M Tris, pH 8.7 with $100 \mu \mathrm{M}$ malonic acid as internal standard), vortexed for $10 \mathrm{~s}$, centrifuged (14000 x g, 10 $\min , 4{ }^{\circ} \mathrm{C}$ ) and the supernatant was filtered using a sterile $0.2 \mu \mathrm{m}$ filter (Minisart). Samples were kept at $-80{ }^{\circ} \mathrm{C}$ until analysis. Prior to analysis the samples were diluted 30 times by running buffer $(0.2 \mathrm{mM}$ 1,2,4-benzenetricarboxylic acid), $8 \mathrm{mM}$ TRIS and $0.3 \mathrm{mM}$ tetradecyltrimethylammonium bromide, $\mathrm{pH} 7.6)$. The fused silica capillary $(0.75 \mu \mathrm{m}$, $80.5 \mathrm{~cm}$ and $72 \mathrm{~cm}$ to detector window) purchased from Agilent (Waldbronn, Germany) was rinsed with $1 \mathrm{M} \mathrm{NaOH}$ before each sequence and pre-treated with water for $0.5 \mathrm{~min}, 0.1 \mathrm{M} \mathrm{NaOH}$ for $1 \mathrm{~min}$ and running buffer for $5 \mathrm{~min}$ before each run. Samples were injected by pressure (35 mbar, 2 s) and run at $-30 \mathrm{kV}$ for 12 min on a G1600A 3DCapillary electrophoresis Instrument (Hewlett-Packard, Waldbronn, Germany). All chemicals were purchased from Sigma Aldrich, Steinheim, Germany.

\section{Analysis of $\beta$-glucosidase (BGL) and $\beta$-glucuronidase (GUS) in caecal samples}

Samples of caecal content ( $0.2 \mathrm{~g})$ were homogenised in $1 \mathrm{~mL}$ PBS, $0.1 \%$ sodium-azide $\mathrm{pH}$ 7.4, and centrifuged (10000 $\mathrm{x} \mathrm{g}, 10 \mathrm{~min}, 4{ }^{\circ} \mathrm{C}$ ). The supernatant was used to determine the activity of BGL and GUS at $37{ }^{\circ} \mathrm{C}$ on an Automated Roche/Hitachi 912 Analyzer (Roche Diagnostics, Mannheim, Germany). BGL was measured by determining the rate of hydrolysis of the substrate p-nitrophenyl-ß-D-glucopyranoside. The amount of p-nitrophenol released was measured at $415 \mathrm{~nm}$ with p-nitrophenol as standard. One unit (U) of enzyme was defined as the amount of enzyme that releases 1 $\mu \mathrm{mol}$ of p-nitrophenol per h. GUS was assayed by determining the rate of release of phenolphthalein from phenolphthalein-ß-D-glucuronide at $540 \mathrm{~nm}$ with phenolphthalein as standard. One unit (U) of enzyme was defined as the amount of enzyme that releases $1 \mu \mathrm{mol}$ of phenolphthalein from the substrate phenolphthalein- $\beta$-D-glucuronide, per hour. The specific activities for both enzymes were reported as U/g caecal content with intra-day variations $<1 \%$. 


\section{RNA isolation and quantitative real-time PCR}

Total RNA was isolated from liver, colon and blood of the first 8 animals of the control group and the first 8 animals of each of the 2 pomace groups without seeds using Qiagen RNeasy Mini kit according to the protocol described by the manufacturer (Qiagen, Hilden, Germany). Reverse transcriptase reactions were performed using Random Hexamer and SuperScript ${ }^{\mathrm{TM}}$ II Reverse Transcriptase kit according to the manufacturer's instructions (Invitrogen). Relative mRNA expression was quantified by Real-time PCR on an ABI 7900HT FAST System using the comparative $\Delta$ Ct method according to ABI manual (TaqMan ${ }^{\circledR}$ Gene Expression Master Mix Protocol, Applied Biosystems, Foster City, CA). PCR amplification for each gene target was performed in triplicate with cDNA samples equivalent to 3 ng RNA. The eukaryotic 18S rRNA was used as internal normalisation standard and data were expressed as fold difference in gene expression relative to a calibrator. Control group samples were pooled and used as a calibrant. TaqMan ${ }^{\circledR}$ Gene Expression Assays used were the following: Eukaryotic 18S rRNA Endogenous Control (catalog number 4352930E); rat Hmgcr (catalog number Rn00695772_g1), rat Cyp7a1 (catalog number Rn00564065_m1).

\section{Faecal primary and secondary bile acids}

The concentration of bile acids in faecal samples was measured by LC/MS/MS by a modification of our previously published method. ${ }^{34}$ Briefly, total faeces were weighed and homogenized with 4 volumes (w/v) of water into a slurry. To a weighed aliquot (approx. $0.3 \mathrm{~g}$ ) of this homogenate was added an internal standard containing the tetra-deuterated ( $\left.\mathrm{D}_{4}\right)$ bile acids, $\mathrm{D}_{4}$-GCA (glycocholic acid), $\mathrm{D}_{4}$-CDOCA (chenodeoxycholic acid), $\mathrm{D}_{4}$-DOCA (deoxycholic acid), $\mathrm{D}_{4}{ }^{-}$ CA (cholic acid), $\mathrm{D}_{4}$-UDOCA (ursodeoxycholic acid), $\mathrm{D}_{4}$ - $\alpha$-MA (alpha-muricholic acid), $\mathrm{D}_{4}$-LCA (lithocholic acid) and extracted three times at $50{ }^{\circ} \mathrm{C}$ with $60 \%$ ethanol. The extract was diluted 1:8 with $0.1 \%$ formic acid and concentrated on an pre-activated Oasis HLB 3cc column (Waters, Milford, MA) and eluted with $800 \mu \mathrm{L} 50 \%$ acetonitrile, $24 \%$ methanol and then with $800 \mu \mathrm{L} 0.1 \% \mathrm{HCOOH}$ in methanol. The combined eluate was evaporated to dryness and redissolved in 15\% ACN, 30\% methanol, and $0.1 \%$ formic acid giving an overall dilution factor of 2.5 . Samples and standards were analysed on an Acquity UPLC with a TQ detector (Waters, operated in MRM mode) with a gradient from phase A to B over 5 min. The mobile phases were $30 \%$ methanol and $0.1 \%$ formic acid (mobile phase A) and $100 \% \mathrm{ACN}$ and $0.1 \%$ formic acid (mobile phase $\mathrm{B}$ ) at a total flow rate of $0.9 \mathrm{~mL} / \mathrm{min}$. Between run $\mathrm{CV} \%$ for the internal standard $(n=4)$ was $3.4 \%$ for $13 \mathrm{C} \mathrm{GCA}, 6.7 \%$ for CDOCA, 7.2\% for DOCA, 4.0\% for CA, 5.1\% for LCA, 6.5\% for $\alpha$-MA and 5.9\% for UDOCA. The individual compounds were quantified using QuanLynx version 4.1 
(Waters) based on the internal standards and external quality control samples. Based on the analytical results for the individual primary and secondary bile acids these were summed for each rat.

\section{FRAP and TEAC analyses of antioxidant activity}

Antioxidant activity in plasma was determined as FRAP as described by Benzie and Strain ${ }^{35}$ and as TEAC using the commercially available total antioxidant status kit Randox NX2332 (Lovmand Diagnostics, Malling, Denmark). Both analyses were performed on a Cobas Mira S (Triolab, Brøndby, Denmark) with CV\% $<2 \%$.

\section{Statistical analysis}

All data are presented as mean $\pm \mathrm{SD}$. Treatment effects were analysed using PROC GLM with treatment (control, 2.1\% apple pomace and 6.3\% apple pomace) as fixed factors, subject as random factor and $+/$ - seeds as covariate. Data that could not meet the criteria of variance homogeneity and normal distribution after transformation were analyzed by nonparametric test (Kruskal-Wallis $H$-test). For all tests a $\mathrm{P}$ value less than 0.05 was considered statistically significant. Pearson correlations were used to identify correlating variables. All statistical analyses were performed using SAS (SAS Enterprise Guide 3, SAS Institute, Cary, NC).

\section{Results}

\section{Chemical composition of apple pomace}

The chemical composition of the apple pomaces was characterised (Table 2). Total dietary polyphenol and pectin contents of the standard pomace (including seeds) were 5.98 and $64.9 \mathrm{~g} / \mathrm{kg}(39.6 \%$ water-soluble pectin), respectively. The main polyphenols were procyanidin B2 (degree of polymerization, $\mathrm{DP}=2$ ) and higher procyanidins $(\mathrm{DP}>2)($ totals $69.0 \%)$, quercetin glycosides (12.6\%), dihydrochalcones $(8.4 \%)$ and (-)-epicatechin $(7.3 \%)$. This is in agreement with data obtained for commercial pomaces. ${ }^{35}$ Seedless pomace contained slightly more polyphenols $(6.24 \mathrm{~g} / \mathrm{kg})$ and more pectin $(96.5 \mathrm{~g} / \mathrm{kg}, 21.1 \%$ water-soluble). Removal of the seeds resulted in decreased total procyanidin content $(50.8 \%)$ and increased quercetin glycosides (33.4\%) which could be explained by the increased proportion of skin in the seedless pomace compared to the standard pomace.

Content of simple sugars was $301 \mathrm{~g} / \mathrm{kg}$ in the standard pomace. Due to processing sugars were reduced by $61.2 \%$ to 117 $\mathrm{g} / \mathrm{kg}$ in the seedless pomace. Seed removal affected the dietary fibre content and the sum of polyphenols to a relatively low extent (Table 2). 
Contents of total carbohydrate, total protein and total fat in apple pomaces differed slightly. Apple pomace including seeds contained $83.3 \%, 6.6 \%$ and $4.6 \%$ carbohydrate, protein and fat, respectively, while the content in a corresponding seedless pomace was $70.7 \%$ for carbohydrate, $5.0 \%$ for protein and $4.2 \%$ for fat. These composition differences lead to slightly lower energy contributions from the seedless pomace compared to standard pomace contributing less than $2 \%$ of the total dietary energy.

\section{Total food intake, body- and liver weight and plasma ALAT enzyme activity}

Data on mean feed- and water intakes per week, body- and relative liver weight, and plasma ALAT enzyme activity at sacrifice in the five groups is shown in Table 3. There was no difference in body weight, feed- or water intakes between the groups $(\mathrm{P}=0.521, \mathrm{P}=0.641$ and $\mathrm{P}=0.204$, respectively), however there was a tendency towards an increased relative liver weight at the highest pomace dosage level compared to control $(\mathrm{P}=0.068)$. The presence of seeds in the pomace did not significantly affect any of these parameters. Plasma ALAT activity was significantly increased in the group fed $6.5 \%$ apple pomace, however only in the group fed pomace without seeds $(\mathrm{P}=0.001)$. The effect was ascribed to increased activity in two of the animals, and we found no other signs of liver toxic effect of the pomace or seeds (Table 3).

\section{Caecal weight, pH, caecal GUS and BGL activities and concentrations of SCFAs}

Caecal contents weight was significantly increased in the highest dosage group compared to control $(\mathrm{P}=0.001)$. The caecal weight or relative caecal weight per se was not affected by any of the treatments $(\mathrm{P}=0.66$ and $\mathrm{P}=0.91$, respectively, data not shown). We found a tendency towards decreased caecal $\mathrm{pH}$ with pomace feeding $(\mathrm{P}=0.091)$ that was still only borderline significant after pooling all pomace-fed groups $(\mathrm{P}=0.067)$. Seeds did not affect $\mathrm{pH}$ values. Caecal GUS and BGL enzyme activities were unaffected by the treatments $(\mathrm{P}=0.697$ and $\mathrm{P}=0.265$, respectively) (Table 4). Likewise, apple pomace did not affect the concentration of propionate in caecal content $(\mathrm{P}=0.151)$. However, there was a tendency towards increased concentration of acetate $(\mathrm{P}=0.064)$ with pomace intake and caecal butyrate concentration was significantly increased with increasing pomace dose $(\mathrm{P}=0.013)$. Inclusion of seeds did not affect the results (Figure 1). Total concentrations of SCFA increased significantly $(\mathrm{P}=0.045)$ with increased dosage level, from $66.4 \pm 19.8$ in the control group, to $85.6 \pm 16.1$ and $84.2 \pm 24.1$ in groups supplemented with $2.1 \%(\mathrm{P}=0.019)$ and $6.5 \%$ $(\mathrm{P}=0.029)$ apple pomace, respectively. There was no significant difference in total concentration of SCFAs between the 
pomace groups $(\mathrm{P}=0.829)$. Total concentration of SCFAs (as well as each SCFA separately) correlated negatively with $\mathrm{pH}(\mathrm{r}=-0.371, \mathrm{P}=0.008)$.

\section{Plasma lipoprotein cholesterol concentrations}

Plasma total-, IDL- and LDL-cholesterol concentrations were significantly decreased by apple pomace compared to control. For both total- and IDL-cholesterol, the decreases were statistically significant at both dosage levels $\left(\mathrm{P}_{2.1 \%}=0.0013\right.$ and $\mathrm{P}_{2.1 \%}=0.021, \mathrm{P}_{6.3 \%}=0.001$ and $\mathrm{P}_{6.3 \%}=0.009$ for total- and IDL-cholesterol respectively). LDLcholesterol was only significantly decreased at the highest dosage level $(\mathrm{P}=0.005)$. We saw no effects on HDL- and VLDL-cholesterol concentrations $(\mathrm{P}=0.085$ and $\mathrm{P}=0.277$ respectively) (Table 5). Total- and LDL-cholesterol concentrations in plasma correlated negatively with acetate $(\mathrm{r}=-0.345, \mathrm{P}=0.014$ and $\mathrm{r}=0.298, \mathrm{P}=0.036$, respectively) and butyrate concentrations ( $\mathrm{r}=-0.372, \mathrm{P}=0.008$ and $\mathrm{r}=-0.331, \mathrm{P}=0.019$, respectively) measured in caecal content. Correlations in the same direction were seen between IDL-cholesterol and butyrate concentrations $(\mathrm{r}=-0.293, \mathrm{P}=0.039)$.

\section{Faecal primary and secondary bile acids}

Feeding apple pomace resulted in significantly increased excretion of total faecal bile acids in the highest dosage group compared to both the control $(\mathrm{P}=0.029)$ and the lowest dosage group $(\mathrm{P}=0.009)$ (Figure 2). Dividing the bile acids into primary and secondary bile acids, revealed that the increase was explained by an increase in excretion of primary bile acids ( $\alpha$-Ma, $\beta$-Ma and $\omega$-Ma) $(\mathrm{P}=0.006)$. Also here, the highest dosage group was significantly different from both control $(\mathrm{P}=0.009)$ and the lowest dosage group $(\mathrm{P}=0.005)$. We observed no significant changes in excretion of total $(\mathrm{P}=0.589)$ (Figure 3 ) or individual secondary bile acids (UDOCA, DOCA or LCA) $(\mathrm{P}=0.642, \mathrm{P}=0.597$ and $\mathrm{P}=0.612$, respectively). Presence of seeds did not affect excretion of bile acids ( $\mathrm{P}>0.05$, data not shown).

We also calculated the effect of apple pomace feeding on concentrations of total-, primary- and secondary bile acids in wet faeces (Figure 3). We found no effect on concentration of total bile acids $(\mathrm{P}=0.242)$ or secondary bile acids $(\mathrm{P}=0.934)$. However, there was a tendency towards increased concentrations of primary bile acids in animals fed apple pomace $(\mathrm{P}=0.071)$.

\section{Gene expression of liver Cyp7a1 and Hmgcr in liver, colon and lymphocytes}

Gene expression of Cyp7a1 did not decrease in liver with pomace feeding $(\mathrm{P}=0.478)$. Expression of Hmgcr in blood and colon was also unaffected by the treatment, even at the higher dosage level $(\mathrm{P}=0.284$ and $\mathrm{P}=0.244$, respectively), and 
we observed a large variation between animals (Figure 4). The expression of Hmgcr in liver was likewise unaffected by pomace feeding $(\mathrm{P}=0.571)$. However, we found that gene expression of hepatic Hmgcr was negatively correlated to caecal propionate concentration $(\mathrm{r}=-0.434, \mathrm{P}=0.034)$. Hmgcr gene expression measured in colon and blood correlated ( $\mathrm{r}=0.489, \mathrm{P}=0.015)$, while none of them were correlated to the expression measured in the liver.

\section{Plasma FRAP and TEAC}

Apple pomace affected plasma TEAC or FRAP values similarly (Table 6). In both cases, apple pomace resulted in a reduction in the values, however only FRAP was significantly decreased with apple pomace feeding $(\mathrm{P}=0.072$ and $\mathrm{P}=0.016$, for TEAC and FRAP, respectively). With FRAP, both dosage levels significantly decreased the marker, however, only in the groups given apple pomace including the seeds ( $\mathrm{P}=0.002$ and $\mathrm{P}=0.015$ in the $2.1 \%$ and $6.3 \%$ pomace groups). In the two groups where pomace did not include seeds, there was no statistically significant effect on FRAP.

\section{Discussion}

Apple pomace, a waste-product from juice production, might be used as a food ingredient in the development of healthier food products because it is rich in dietary fibre and polyphenols which both have been linked to decreased plasma cholesterol concentrations. We used two qualities of pomace with and without the seed component. The process of removing the seeds from the pomace reduced sugars by about $61 \%$, and with composition data from apple pomaces produced using the same cultivar, we estimate that seeds also contributed approx. $0.04 \mathrm{~g}$ fat and $0.16 \mathrm{~g}$ protein for each per cent to the feed composition leading to minimal differences in the overall energy intakes. Furthermore, we saw no differences in feed intake between the groups. Apple seeds contain the cyanogenic glycoside, amygdalin, that may pose a health risk if consumed in large amounts due to the conversion of amygdalin into hydrocyanic acid (HCN) upon physical processing (grinding or chewing). The content of seeds in apple pomace is about $7 \%{ }^{36}$ and apple seeds contain up to $4 \mathrm{mg} / \mathrm{g}$ of amygdalin. ${ }^{37}$ Taking these data into consideration the exposure to amygdalin in the present study would be in the range $0.17-0,52 \mathrm{mg} / \mathrm{d}$ in rats fed $2.1-6,5 \%$ apple pomace, which is negligible in terms of risk. For cyanide a no observed adverse effect level of $0.36 \mathrm{mg}$ cyanide $/ \mathrm{kg} / \mathrm{d}$ was reported in rats, ${ }^{38}$ corresponding to an daily intake of $6.1 \mathrm{mg}$ amygdalin $/ \mathrm{kg} / \mathrm{d}$, Assuming complete degradation of amygdalin ( $1 \mathrm{~g}$ of amygdalin releasing $59 \mathrm{mg} \mathrm{HCN}$ ), this would correspond to a much higher intake of $6.1 \mathrm{mg}$ amygdalin $/ \mathrm{kg} / \mathrm{d}$ compared to the present study. This is corroborated by literature data showing that defatted apple seeds fed to rats at a very high dose (amygdalin content of $13.1 \mathrm{mg} / \mathrm{g}$ ) did not 
exert any observable adverse effects after two weeks. ${ }^{39}$ Low nutritional quality of the apple seed protein was reported as the main issue in that study. In the present study, we confirmed the previously reported hypocholesterolemic effect of apple pomace, in that both total-, IDL- and LDL-cholesterol concentrations were decreased following apple pomace feeding. It has been suggested that apple pomace only has hypolipidemic effects in cholesterol fed or obese rodents. ${ }^{14,40}$ However, we report here a cholesterol lowering effect of apple pomace in normal weight F344 rats receiving a diet with no added cholesterol. Aprikian et al. have shown that apple pectin and apple phenolics together have a much greater effect on the lipid profile than each has by themselves, suggesting that apple pomace which is rich in both, might have potential for commercial use as a bioactive food ingredient. ${ }^{11}$ It should be stressed that many industrial pomaces have been pectinase treated for clear juice production, while our current pomace was from cloudy apple juice production and had high contents of pectin as well as apple polyphenols. Overall, despite some minor differences in the composition of the pomaces with and without seeds we observed only few differences between their effects.

Several mechanisms have been proposed to explain the cholesterol-lowering effect of apple pomace. Among these are a decreased cholesterol uptake and inhibition of bile acid reabsorption due to the viscous properties of the dietary fibres, ${ }^{41}$ and suppression of hepatic cholesterol biosynthesis caused by SCFA. ${ }^{29}$ Besides the observed hypocholesterolemic effect, apple pomace affected several markers related to gut health. The positive effects on caecum weight and the increase in concentration of SCFA indicate stimulation of the intestinal microbiota most likely caused by the fibre present in the apple pomace. This is in line with previous findings, showing increased microbial activity leading to increased production of SCFA with a diet rich in apple fibres. ${ }^{42,43}$ No dose-response for SCFA concentration was observed indicating that the bulking effects of the fibre shown by the higher weight of caecum content is the major factor explaining the dose-response observed for total SCFA content with pomace dose. All three measured SCFAs increased with increasing pomace intake, but only butyrate reached statistical significance. Increases in butyrate concentrations have previously been ascribed to the microbial breakdown of insoluble cell-wall material, ${ }^{44}$ and we have recently reported that also apple pectin can change the microbiota of rats, favouring the population of butyrate producing Clostridiales, ${ }^{45}$ which could explain the higher production of butyrate with apple pomace observed in the present study. This product of microbial metabolism has been linked to improved gut health, being the main source of energy for colon epithelium cells ${ }^{46}$ and able to induce apoptosis, reduce metastasis in colon cell lines and protect from carcinogens by enhancing the expression of genes involved in detoxification. ${ }^{47}$

Adding $6.5 \%$ apple pomace to the diet also resulted in increased excretion of bile acids, an increase that was due to higher excretion of primary bile acids. This could explain the lowered cholesterol concentrations, since stimulation of 
bile acid biosynthesis from cholesterol would lead to a decrease in cholesterol stores. Apple dietary fibres have previously been reported to increase bile acid excretion. ${ }^{42} \mathrm{We}$ also investigated the effect of apple pomace on bacterial activities of GUS and BGL. Lowered GUS activities have been shown to reduce toxicity of carcinogens in some studies ${ }^{48}$ and increased activity might affect the risk of colon cancer negatively. Others have suggested that increased GUS might activate glucuronidated polyphenols, which is considered a beneficial effect. ${ }^{49}$ We observed no effect in this study indicating that the pomace has a different effect compared with apple pectin ${ }^{45}$ possibly due to opposite effects of the polyphenols and pectin components of the pomace.

Apple pomace stimulated caecal fermentation, resulting in increased concentrations of SCFA and increased excretion of primary bile acids which all might explain the cholesterol-lowering effects of apple pomace. To further investigate the mechanism behind these effects we measured the expression of genes involved in cholesterol (Hmgcr) and bile acid (Cyp7a1) biosynthesis. SCFA have possible systemic effects on lipid metabolism as they have been shown to inhibit liver cholesterol biosynthesis in experimental animals. The increase in bile acid excretion following interaction with fibre is likely to result in decreased reabsorption of bile acids into the liver. Cholesterol catabolism may thereby be increased on the expense of its biosynthesis. ${ }^{50,51} \mathrm{We}$ did not see a significant effect on gene expression of the ratelimiting step in cholesterol biosynthesis, Hmgcr, in either blood, liver or colon tissues. However, we note that the expressions tended to decrease so there was no indication of a compensatory increase in the hepatic or peripheral cholesterol biosynthesis. The lack of increase in Hmgcr might be a result of increased production of SCFA. It is generally believed that SCFAs exert their cholesterol-lowering effect through reduction of hepatic cholesterol biosynthesis. ${ }^{29}$ However, we were not able to confirm this, even though we saw decreased expression of Hmgcr in all tested tissues/cells. Likewise, we saw no statistically significant effect of pomace feeding on gene expression of hepatic Cyp7a1, encoding the rate-limiting enzyme in bile acid biosynthesis from cholesterol. Even though the expression tended to decrease with pomace feeding, the variations within groups were too high, so lack of power may have prohibited our ability with the present group size to link the cholesterol-lowering effect of apple pomace to the expression of the selected genes involved in biosynthesis of cholesterol and bile acids, respectively. Yet, this does not exclude that increased biosynthesis of bile acids at the expense of cholesterol is taking place. The regulation may be at the translational rather than the transcriptional level. Higher activity of cholesterol $7 \alpha$-hydroxylase, the enzyme encoded by Cyp7a1, with pectin feeding has previously been linked to higher bile acid concentrations and support the hypothesis that the hypocholesterolemic effect of soluble fibres such as pectin is modulated through increased synthesis and 
therefore pool size of bile acids. ${ }^{52}$ We were not able to confirm this by determining the enzyme activity in the present study.

From our results, it seems that apple pomace is able to affect both proposed mechanisms behind the cholesterollowering effect of dietary fibre, involving increased production of SCFA and increased excretion of bile acids. However, we are not able to explain this by changes in the expression of genes involved in cholesterol and bile acid biosynthesis. An increase in SCFA concentrations has been reported to suppress cholesterol biosynthesis, ${ }^{29}$ while we would expect induction of cholesterol and bile acid biosynthesis to take place as a result of increased bile acid excretion. These opposite effects might explain the lack of change in the net hepatic cholesterol biosynthesis rate, as we report here.

Besides its fibre content, apple pomace is a good source of polyphenols, with reported antioxidant activity in vitro. Dietary polyphenols, due to their antioxidant properties, might act as a protective antioxidant barrier in the gut system. ${ }^{53}$ Dietary polyphenols are, once they reach the colon, extensively metabolised by the gut microbiota to form simple phenolic acids which are more readily absorbed. The presence of pectin might increase absorption as shown in mice. ${ }^{54}$ We investigated the effect of apple pomace feeding on markers of antioxidant activity using two different methods. We found that apple pomace significantly decreased plasma FRAP. A high fibre diet has previously been associated with decreased blood uric acid concentrations compared to a less fibre-rich diet. ${ }^{55}$ Uric acid is a major contributor to FRAP, and recent studies have indicated that high uric acid concentrations are implicated in the development of hypertension, and furthermore, uric acid has been linked to risk of CVD ${ }^{56}$ Based on this, decreases in FRAP might therefore be desirable. It has actually been suggested that an increased plasma antioxidant capacity expressed as FRAP could be regarded as a risk factor of CVD rather than a protective factor. ${ }^{57}$ Even though FRAP decreased in all pomace groups, the decrease was only statistically significant in the groups fed apple pomace including seeds. Why this is so is not clear, some component of the seeds may have a specific effect that needs to be investigated further. Not surprisingly, a similar negative effect of apple pomace was seen on TEAC that could likewise be explained by a decrease in uric acid levels. However, the effect on TEAC was not statistically significant. The results suggest that apple pomace, in spite of its relatively high concentration of polyphenols, decreases plasma antioxidant activity, which is probably related to the known effect of fibre on uric acid concentrations. If the effect is linked to uric acid concentrations, this might potentially reduce the risk of hypertension, and thereby risk of CVD.

In the present study we have confirmed that apple pomace improves the lipid profile and positively affects the gut environment. Both effects on levels of SCFA and bile acids were observed and might be responsible for the cholesterol- 
lowering effects. However, effects on expression of the selected genes involved in cholesterol and bile acid biosynthesis could not explain these findings. Apple pomace might be an attractive food ingredient, based on the present results and results from an earlier human intervention study that we performed in healthy, normal-weight subjects. ${ }^{21}$ In that study we investigating the effect of whole apples, apple pomace, cloudy and clear apple juices on blood lipids and found that compared to clear apples juice the cholesterol-lowering effect of whole apples and apple pomace was linked to the fibre component. Altogether, the results indicate that apple pomace might have a health beneficial effect and that the presence of apple seeds does not pose any health risk.

EFSA has set an acute reference dose (ARfD) for cyanide of $20 \mu \mathrm{g} / \mathrm{kg} \cdot{ }^{38}$ Applying the assumptions made above concerning seed content in pomace, amygdalin concentration in seeds and release of cyanide from seeds, this would correspond to a daily intake of approximately $90 \mathrm{~g}$ pomace. The dose levels $(2.1 \%$ and $6.5 \%)$ used in the present study correspond to a daily human intake of $94.5 \mathrm{~g}$ and $292.5 \mathrm{~g}$ of apple pomace, respectively, but adjusting for the difference in basal metabolic rate between rat and man, the dose is more comparable to the intake of $\sim 20-60 \mathrm{~g}$ apple pomace which is within the ARfD and corresponds to about 400-1300 g whole apples (or 3-8 apples a day). The lowest dose level corresponds to the one used in our human study, where participants consumed $500 \mathrm{~g}$ apple (3-4 apples) or $22 \mathrm{~g}$ apple pomace a day. Similar mechanisms were affected in the two studies which might open for the potential use of apple pomace as an active and possibly health promoting food ingredient in the future assuming that other safety parameters such as contents of pesticides and heavy metals are within safety limits.

\section{Conflict of interest}

There are no conflicts of interest to declare.

\section{Acknowledgements}

The authors would like to thank Vibeke Kegel, Pia Madsen, Annette Landin, Lars Bentzen, Alicja Mortensen, Mette Kristensen and Rikke Rentsch for excellent technical assistance, and Anne Ørngreen and her staff for professional handling of the animals. This work is part of the ISAFRUIT project, a research project financially supported by the Commission of the European Communities under the Sixth Framework Programme: Food Quality and Safety, contract no. 016279 "Increasing fruit consumption through a trans-disciplinary approach delivering high quality produce from environmentally friendly, sustainable production methods (ISAFRUIT)". It does not necessarily reflect its view and in no way anticipates the Commission's policy in this area. 


\section{References}

1. Hung, H.C.; Joshipura, K.J.; Jiang, R.; Hu, F.B.; Hunter, D.; Smith-Warner, S.A.; Colditz, G.A.; Rosner, B.; Spiegelman, D.; Willett, W.C. Fruit and vegetable intake and risk of major chronic disease. J. Natl. Cancer Inst. 2004, $96,1577-1584$

2. Dauchet, L.; Amouyel, P.; Hercberg, S.; Dallongeville, J. Fruit and vegetable consumption and risk of coronary heart disease: a meta-analysis of cohort studies. J. Nutr. 2006, 136, 2588-2593.

3. Johnsen, S.P.; Overvad, K.; Stripp, C.; Tjonneland, A.; Husted, S.E.; Sorensen, H.T. Intake of fruit and vegetables and the risk of ischemic stroke in a cohort of Danish men and women. Am. J. Clin. Nutr. 2003, 78, 57-64.

4. Takachi, R.; Inoue, M.; Ishihara, J.; Kurahashi, N.; Iwasaki, M.; Sasazuki, S.; Iso, H.; Tsubono, Y.; Tsugane, S; JPHC Study Group. Fruit and vegetable intake and risk of total cancer and cardiovascular disease: Japan Public Health Center-Based Prospective Study. Am. J. Epidemiol. 2008, 167, 59-70.

5. Boyer, J.; Liu, R.H. Apple phytochemicals and their health benefits. Nutr. J. 2004, 3, 5.

6. Mink, P.J.; Scrafford, C.G.; Barraj, L.M.; Harnack, L.; Hong, C.P.; Nettleton, J.A.; Jacobs, D.R.Jr. Flavonoid intake and cardiovascular disease mortality: a prospective study in postmenopausal women. Am. J. Clin. Nutr. 2007, 85, 895909.

7. Sesso, H.D.; Gaziano, J.M.; Liu, S.; Buring, J.E. Flavonoid intake and the risk of cardiovascular disease in women. Am. J. Clin. Nutr. 2003, 77, 1400-1408.

8. Sable-Amplis, R.; Sicart, R.; Bluthe, E. Decreased cholesterol ester levels in tissues of hamsters fed with apple fiber enriched diet. Nutr. Rep. Int. 1983, 27, 881-889.

9. Sable-Amplis, R.; Sicart, R. Cholesterol synthesis and esterification in hypercholesterolemic hamsters: Influence of a fruit-enriched diet. Nutr. Res. 1986, 6, 689-697.

10. Sable-Amplis, R.; Sicart, R.; Dupouy, D. Reduced cholesterol 7alfa-hydroxylase activity in hypercholesterolemic hamsters. Preventive effect of a fruit-enriched diet. Nutr. Res. 1987, 7, 645-653.

11. Aprikian, O.; Duclos, V.; Guyot, S.; Besson, C.; Manach, C.; Bernalier, A.; Morand, C.; Rémésy, C.; Demigné, C. Apple pectin and a polyphenol-rich apple concentrate are more effective together than separately on cecal fermentations and plasma lipids in rats. J. Nutr. 2003, 133, 1860-1865.

12. Bobek, P.; Ginter, E.; Jurcovicova, M.; Ozdin, L.; Cerven, J.; Babala, J. Effect of dehydrated apple products on the serum and liver lipids in Syrian hamsters. Nahrung 1990, 34, 783-789. 
13. Leontowicz, H.; Gorinstein, S.; Lojek, A.; Leontowicz, M.; Ci;z, M.; Soliva-Fortuny, R.; Park, Y.S.; Jung, S.T.; Trakhtenberg, S.; Martin-Belloso, O. Comparative content of some bioactive compounds in apples, peaches and pears and their influence on lipids and antioxidant capacity in rats. J. Nutr. Biochem. 2002, 13, 603-610.

14. Leontowicz, M.; Gorinstein, S.; Elzbieta, B.; Leontowicz, H.; Kulasek, G.; Trakhtenberg, S. Sugar beet pulp and apple pomace dietary fibers improve lipid metabolism in rats fed cholesterol. Food Chem. 2001, 72, 73-78.

15. Canella, C.; Golinelli, G.; Melli, A. Apple pulp and cholesteremia. Boll. Soc. Ital. Cardiol. 1963, 8, 329-335.

16. Girault, A.; Bled, F.; Bouvier, J-M.; Cornet, D.; Girault, M. Effets bénéfiques de la consommation de pommes sur le métabolisme lipidique chez l'homme. Cardiologie 1988, 76-9.

17. Gormley, T.R.; Kevany, J.; Egan, J.P.; McFarlane, R. Effect of apples on serum cholesterol levels in humans. Ir. J. Fd. Sci. Technol. 1977, 1, 117-128.

18. Sable-Amplis, R.; Sicart, R.; Agid, R. Further studies on the cholesterol-lowering effect of apple in human. Biochemical mechanims involved. Nutr. Res. 1983, 3, 325-328.

19. Nagasako-Akazome, Y.; Kanda, T.; Ikeda, M.; Shimasaki, H. Serum Cholesterol-Lowering Effect of Apple Polyphenols in Healthy Subjects. J. Oleo Sci. 2005, 54,143-151.

20. Nagasako-Akazome, Y.; Kanda, T.; Ohtake, Y.; Shimasaki, H.; Kobayashi, T. Apple polyphenols influence cholesterol metabolism in healthy subjects with relatively high body mass index. J. Oleo Sci. 2007, 56, 417-428.

21. Ravn-Haren, G.; Dragsted, L.O.; Buch-Andersen, T.; Jensen, E.N.; Jensen, R.I.; Nemeth-Balogh, M.; Paulovicsova, B.; Bergström, A.; Wilcks, A.; Licht, T.R.; Markowski, J.; Bügel, S. Intake of whole apples or clear apple juice has contrasting effects on plasma lipids in healthy volunteers. Eur. J. Nutr. 2013, 52, 1875-1889.

22. Scalbert, A.; Morand, C.; Manach, C.; Remesy, C. Absorption and metabolism of polyphenols in the gut and impact on health. Biomed. Pharmacother. 2002, 56, 276-282.

23. Groudeva, J. Application of granulated apple pectin in the treatment of hyperlipoproteinaemia. I. Deriving the regression equation to describe the changes. Z. Lebensm. Unters. Forsch. A 1997, 204, 374-378.

24. Jenkins, D.J.; Newton, C.; Leeds, A.R.; Cummings, J.H. Effect of pectin, guar gum, and wheat fibre on serumcholesterol. Lancet 1975, 1, 1116-1117.

25. Tinker, L.F.; Davis, P.A.; Schneeman, B.O. Prune fiber or pectin compared with cellulose lowers plasma and liver lipids in rats with diet-induced hyperlipidemia. J. Nutr. 1994, 124, 31-40.

26. Vahouny, G.V.; Roy, T.; Gallo, L.L.; Story, J.A.; Kritchevsky, D.; Cassidy, M. Dietary fibers. III. Effects of chronic intake on cholesterol absorption and metabolism in the rat. Am. J. Clin. Nutr. 1980, 33, 2182-2191. 
27. Myant, N.B.; Mitropoulos, K.A. Cholesterol 7 alpha-hydroxylase. J. Lipid Res. 1977, 18, 135-153.

28. Wahlström, A.; Sayin, S.I.; Marschall, H-U; Bäckhed, F. Intestinal crosstalk between bile acids and microbiota and its impact on host metabolism. Cell Metab. 2016, 24, 41-50.

29. Hara, H.; Haga, S.; Aoyama, Y.; Kiriyama, S. Short-chain fatty acids suppress cholesterol synthesis in rat liver and intestine. J. Nutr. 1999, 129, 942-948.

30. Tsao, R.; Yang, R. Optimization of a new mobile phase to know the complex and real polyphenolic composition: towards a total phenolic index using high-performance liquid chromatography. J. Chromatogr. A 2003, 1018, 29-40.

31. Guyot, S.; Marnet, N.; Laraba, D.; Sanoner P.; Drilleau, J.-F. Reversed-phase HPLC following thiolysis for quantitative estimation and characterization of the four main classes of phenolic compounds in different tissue zones of a French cider apple variety (Malus domestica var. Kermerrien). J. Agric. Food Chem. 1998, 46, 1698-1705.

32. Terpstra, A.H.; Woodward, C.J.; Sanchez-Muniz, F.J. Improved techniques for the separation of serum lipoproteins by density gradient ultracentrifugation: visualization by prestaining and rapid separation of serum lipoproteins from small volumes of serum. Anal. Biochem. 1981, 111, 149-157.

33. Westergaard, B.; Hansen, H.C.B.; Borgaard, O.K. Determination of anions in soil solutions by capillary zone electrophoresis. Analyst 1998, 123, 721-724.

34. Roldan-Marin, E.; Jensen, R.I.; Krath, B.N.; Kristensen, M.; Poulsen, M.; Cano, M.P.; Sanchez-Moreno, C.; Dragsted, L.O. An onion byproduct affects plasma lipids in healthy rats. J. Agric. Food Chem. 2010, 58, 5308-5314. 35. Benzie, I.F.; Strain, J.J. The ferric reducing ability of plasma (FRAP) as a measure of "antioxidant power": the FRAP assay. Anal. Biochem. 1996, 239, 70-76.

36. Kołodziejczyk, K.; Markowski, J.; Kosmala, M.; Król, B.; Płocharski, W. Apple pomace as a potential source of nutraceutical products. Pol. J. Food Nutr. Sci. 2007, 57, 291-295.

37. Bolarinwa, I.F.; Orfila, C.; Morgan, M.R. Determination of amygdalin in apple seeds, fresh apples and processed apple juices. Food Chem. 2015, 170, 437-442.

38. EFSA CONTAM Panel (EFSA Panel on Contaminants in the Food Chain). Scientific opinion on the acute health risks related to the presence of cyanogenic glycosides in raw apricot kernels and products derived from raw apricot kernels. EFSA Journal. 2016, 14, 4424-4470.

39. Opyd, P.M.; Jurgoński, A.; Juśkiewicz, J.; Milala, J.; Zduńczyk, Z.; Król, B. Nutritional and Health-Related Effects of a Diet Containing Apple Seed Meal in Rats: The Case of Amygdalin. Nutrients. 2017, 9, 1091-1103. 
40. Aprikian, O.; Busserolles, J.; Manach, C.; Mazur, A.; Morand, C.; Davicco, M.J.; Besson, C.; Rayssiguier, Y.; Rémésy, C.; Demigné, C. Lyophilized apple counteracts the development of hypercholesterolemia, oxidative stress, and renal dysfunction in obese Zucker rats. J. Nutr. 2002, 132, 1969-1976.

41. Vahouny, G.V.; Roy, T.; Gallo, L.L.; Story, J.A.; Kritchevsky, D.; Cassidy, M. Dietary fibers. III. Effects of chronic intake on cholesterol absorption and metabolism in the rat. Am. J. Clin. Nutr. 1980, 33, 2182-2191.

42. Sembries, S.; Dongowski, G.; Mehrlander, K.; Will, F.; Dietrich, H. Dietary fiber-rich colloids from apple pomace extraction juices do not affect food intake and blood serum lipid levels, but enhance fecal excretion of steroids in rats. $J$. Nutr. Biochem. 2004, 15, 296-302.

43. Sembries, S.; Dongowski, G.; Mehrlander, K.; Will, F., Dietrich, H. Physiological effects of extraction juices from apple, grape, and red beet pomaces in rats. J. Agric. Food Chem. 2006, 54, 10269-10280.

44. Sembries, S.; Dongowski, G.; Jacobasch, G.; Mehrlander, K.; Will, F.; Dietrich, H. Effects of dietary fibre-rich juice colloids from apple pomace extraction juices on intestinal fermentation products and microbiota in rats. Br. J. Nutr. 2003, 90, 607-615.

45. Licht, T.R.; Hansen, M.; Bergström, A.; Poulsen, M.; Krath, B.N.; Markowski, J.; Dragsted, L.O.; Wilcks, A. Effects of apples and specific apple components on the cecal environment of conventional rats: role of apple pectin. BMC Microbiol. 2010, 10:13.

46. Roediger, W.E. Utilization of nutrients by isolated epithelial cells of the rat colon. Gastroenterology 1982, 83, 424429.

47. Pool-Zobel, B.L.; Sauer, J. Overview of experimental data on reduction of colorectal cancer risk by inulin-type fructans. J. Nutr. 2007, 137, 2580S-2584S.

48. Humblot, C.; Murkovic, M.; Rigottier-Gois, L.; Bensaada, M.; Bouclet, A.; Andrieux, C.; Anba, J.; Rabot, S. Betaglucuronidase in human intestinal microbiota is necessary for the colonic genotoxicity of the food-borne carcinogen 2amino-3-methylimidazo[4,5-f]quinoline in rats. Carcinogenesis 2007, 28, 2419-2425.

49. Manach, C.; Scalbert, A.; Morand, C.; Remesy, C.; Jimenez, L. Polyphenols: food sources and bioavailability. Am. J. Clin. Nutr. 2004, 79, 727-747.

50. Jenkins, D.J.A.; Wolever, T.M.S.; Rao, A.V.; Hegele, R.A.; Mitchell, S.J.; Ransom, T.P.P.; Boctor, D.L.; Spadafora, P.J.; Jenkins, A.L.; Mehling, C.; Relle, L.K.; Connelly, P.W.; Story, J.A.; Furumoto, E.J.; Corey, P.; Würsch, P. Effect on blood lipids of very high intakes of fiber in diets low in saturated fat and cholesterol. N. Engl. J. Med. 1993, 329, 21-26. 
51. Vahouny, G.V.; Tombes, R.; Cassidy, M.M.; Kritchevsky, D.; Gallo, L.L. Dietary fibers: V. Binding of bile salts, phospholipids and cholesterol from mixed micelles by bile acid sequestrants and dietary fibers. Lipids 1980, 15, 10121018.

52. Matheson, H.B.; Colon, I.S.; Story, J.A. Cholesterol 7 alpha-hydroxylase activity is increased by dietary modification with psyllium hydrocolloid, pectin, cholesterol and cholestyramine in rats. J. Nutr. 1995, 125, 454-458. 53. Giovannelli, L.; Testa, G.; De Filippo, C.; Cheynier, V.; Clifford, M.N.; Dolara, P. Effect of complex polyphenols and tannins from red wine on DNA oxidative damage of rat colon mucosa in vivo. Eur. J. Nutr. 2000, 39, $207-212$. 54. Tamura, M.; Nakagawa, H.; Tsushida, T.; Hirayama, K.; Itoh, K. Effect of pectin enhancement on plasma quercetin and fecal flora in rutin-supplemented mice. J. Food Sci. 2007, 72, S648-S651.

55. Sun, S.Z.; Flickinger, B.D.; Williamson-Hughes, P.S.; Empie, M.W. Lack of association between dietary fructose and hyperuricemia risk in adults. Nutr. Metab. (Lond) 2010, 7:16.

56. Fang, J.; Alderman, M.H. Serum uric acid and cardiovascular mortality the NHANES I epidemiologic follow-up study, 1971-1992. National Health and Nutrition Examination Survey. JAMA 2000, 283, 2404-2410.

57. Auclair, S.; Silberberg, M.; Gueux, E.; Morand, C.; Mazur, A.; Milenkovic, D.; Scalbert, A. Apple polyphenols and fibers attenuate atherosclerosis in apolipoprotein E-deficient mice. J. Agric. Food Chem. 2008, 56, 5558-5563. 
Table 1 Composition of the experimental diets

\begin{tabular}{lccc}
\hline Ingredients (g/ kg feed) & Control & $2.1 \%$ pomace & $6.5 \%$ pomace \\
\hline Na-caseinate & 200 & 200 & 200 \\
Sucrose & 100 & 93 & 78 \\
Cornstarch & 456 & 446 & 426 \\
Soybean oil with ADEK vitamins ${ }^{\mathrm{a}}$ & 50 & 50 & 50 \\
Soybean oil $_{\text {Corn oil }}$ & 20 & 20 & 20 \\
Cellulose & 80 & 80 & 80 \\
Mineral mixture & 50 & 46 & 37 \\
Vitamin mixture $^{\mathrm{c}}$ & 32 & 32 & 32 \\
Apple pomace & 12 & 12 & 12
\end{tabular}

${ }^{\mathrm{a} C}$ Containing in $\mathrm{mg} / \mathrm{kg}$ diet: 5000 (IU) vitamin $\mathrm{A}, 1000$ (IU) vitamin $\mathrm{D}_{3}, 50$ (IU) vitamin $\mathrm{E}, 1$ phylloquinine

${ }^{\mathrm{b}}$ Containing in mg/kg diet: $2500 \mathrm{Ca}, 1600 \mathrm{P}, 3600 \mathrm{~K}, 300 \mathrm{~S}, 2500 \mathrm{Na}, 1500 \mathrm{Cl}, 600 \mathrm{Mg}, 34 \mathrm{Fe}, 30 \mathrm{Zn}, 10 \mathrm{Mn}, 0.20 \mathrm{I}$,

0.15 Mo, 0.15 Se, 2.5 Si, 1.0 Cr, 1.0 F, 0.5 Ni, 0.5 B, 0.1 Li, 0.1 V, 0.07 Co

${ }^{\mathrm{c}}$ Containing in $\mathrm{mg} / \mathrm{kg}$ diet: 5 thiamin, 6 riboflavin, 8 pyridoxol, 2 folic acid, 0.3 D-biotin, 0.03 vitamin B-12, 20 pantothenate, 2600 cholinhydrogentartrat, 400 inositol, 40 nicotinic acid, 40 p-aminobenzoic acid, 1000 methionine, 2000 L-cystine 
Table 2 Composition of the pomaces

\begin{tabular}{|c|c|c|c|}
\hline Basic pomace parameters & Unit & Standard pomace & Seedless pomace \\
\hline Dry matter ${ }^{\mathrm{a}}$ & $\%$ & 97.5 & 96.3 \\
\hline Ashes $^{\text {bc }}$ & $\mathrm{g} / \mathrm{kg}$ & 15 & 17.5 \\
\hline Sugars total ${ }^{\mathrm{c}}$, out of which: & $\mathrm{g} / \mathrm{kg}$ & 300.6 & 116.6 \\
\hline Sucrose $^{c}$ & $\mathrm{~g} / \mathrm{kg}$ & 21.8 & 13.6 \\
\hline Glucose $^{\mathrm{c}}$ & $\mathrm{g} / \mathrm{kg}$ & 66.2 & 27.9 \\
\hline Fructose $^{c}$ & $\mathrm{~g} / \mathrm{kg}$ & 212.6 & 75.1 \\
\hline Sorbitol $^{\mathrm{c}}$ & $\mathrm{g} / \mathrm{kg}$ & 19.7 & 6.7 \\
\hline Total dietary fibre $^{\mathrm{d}}$ & $(\%)$ & 49.9 & 59.0 \\
\hline Total pectins ${ }^{\mathrm{e}}$ & $\mathrm{g} / \mathrm{kg}$ & 64.9 & 96.5 \\
\hline Water soluble pectins ${ }^{\mathrm{e}}$ & $\mathrm{g} / \mathrm{kg}$ & 25.7 & 20.4 \\
\hline Total carbohydrate ${ }^{\mathrm{bf}^{*}}$ & $\mathrm{~g} / \mathrm{kg}$ & 833 & 707 \\
\hline Total protein ${ }^{\text {bg* }}$ & $\mathrm{g} / \mathrm{kg}$ & 66 & 50 \\
\hline Total fat ${ }^{\mathrm{bh} *}$ & $\mathrm{~g} / \mathrm{kg}$ & 46 & 42 \\
\hline \multicolumn{4}{|l|}{ Phenolic compounds composition ${ }^{\mathrm{i}}$} \\
\hline$(+)$-catechin & $\mathrm{mg} / \mathrm{kg}$ & 42 & 36 \\
\hline (-)-epicatechin & $\mathrm{mg} / \mathrm{kg}$ & 439 & 431 \\
\hline Procyanidins & $\mathrm{mg} / \mathrm{kg}$ & 3670 & 2843 \\
\hline degree of polymerization & - & 5.1 & 5.3 \\
\hline procyanidin B2 & $\mathrm{mg} / \mathrm{kg}$ & 458 & 327 \\
\hline caffeoylquinic acid & $\mathrm{mg} / \mathrm{kg}$ & 103 & 58 \\
\hline 4-(p-coumaroyl)-quinic acid & $\mathrm{mg} / \mathrm{kg}$ & 14 & 6 \\
\hline dihydrochalcones (PLZ+XPL) & $\mathrm{mg} / \mathrm{kg}$ & 503 & 454 \\
\hline Quercetin glycosides & $\mathrm{mg} / \mathrm{kg}$ & 754 & 2088 \\
\hline Sum of phenolic compounds & $\mathrm{mg} / \mathrm{kg}$ & 5983 & 6243 \\
\hline
\end{tabular}

The following methods were used: ${ }^{\mathrm{a}}$ IFU $61,{ }^{\mathrm{b}}$ Analysed at Eurofins by accredited methods, ${ }^{\mathrm{c}} \mathrm{NMKL}$ 173:2005, ${ }^{\mathrm{d}}$ AOAC, ${ }^{\mathrm{e}}$ IFU 26, ${ }^{\mathrm{f}}$ AOAC 982.14, ${ }^{\mathrm{g}}$ NMKL 6:2003 modified Kjeldahl, ${ }^{\mathrm{h}}$ ISO 11085:2015, ${ }^{\mathrm{i}}$ measured by HPLC as described in Materials and Methods. ${ }^{*}$ Determined in a separate batch of standard and seedless pomace. 
Table 3 Body weight, feed and water intakes, relative liver weight and plasma ALAT enzyme activity after 4 weeks feeding of control

diet, or control diet added $2.1 \%$ or $6.5 \%$ apple pomace ${ }^{\mathrm{a}}$

\begin{tabular}{|c|c|c|c|c|c|c|c|}
\hline Group & $\mathrm{N}$ & $\begin{array}{c}\text { Body weight } \\
(\mathrm{g})\end{array}$ & $\begin{array}{c}\text { Feed intake } \\
\text { (g/week) }\end{array}$ & $\begin{array}{c}\text { Water intake } \\
\text { (g/week) }\end{array}$ & $\begin{array}{c}\text { Relative liver weight } \\
\text { (g/kg body weight) }\end{array}$ & $\mathrm{n}$ & $\begin{array}{l}\text { ALAT } \\
(\mathrm{U} / \mathrm{L})\end{array}$ \\
\hline Control & 10 & $188 \pm 12$ & $178 \pm 11$ & $195 \pm 13$ & $31.3 \pm 1.0$ & 9 & $103 \pm 10$ \\
\hline $2.1 \%$ pomace $(-$ seeds $)$ & 10 & $188 \pm 10$ & $182 \pm 13$ & $206 \pm 13$ & $31.4 \pm 0.2$ & 9 & $105 \pm 18$ \\
\hline $2.1 \%$ pomace $(+$ seeds $)$ & 10 & $194 \pm 15$ & $184 \pm 16$ & $212 \pm 18$ & $31.1 \pm 1.3$ & 10 & $96 \pm 11$ \\
\hline $2.1 \%$ pomace (both groups) & 20 & $191 \pm 13$ & $183 \pm 14$ & $209 \pm 15$ & $31.2 \pm 1.2$ & 19 & $101 \pm 15$ \\
\hline $6.5 \%$ pomace $(-$ seeds $)$ & 10 & $190 \pm 18$ & $190 \pm 21$ & $210 \pm 19$ & $32.3 \pm 1.0$ & 10 & $125^{\mathrm{b}} \pm 20$ \\
\hline $6.5 \%$ pomace $(+$ seeds $)$ & 10 & $194 \pm 11$ & $189 \pm 20$ & $219 \pm 25$ & $31.7 \pm 0.9$ & 8 & $108 \pm 14$ \\
\hline $6.5 \%$ pomace (both groups) & 20 & $192 \pm 14$ & $189 \pm 20$ & $214 \pm 21$ & $32.0 \pm 1.0$ & 18 & $117^{\mathrm{b}} \pm 19$ \\
\hline
\end{tabular}

${ }^{\mathrm{a}}$ Data are presented as mean and SD

${ }^{\mathrm{b}}$ Statistically significantly different from control $(\mathrm{P}<0.05)$ (ANOVA)

ALAT alanine aminotransferase 
Table 4 Caecal parameters in rats fed control diet, or control diet added $2.1 \%$ or $6.5 \%$ apple pomace for 4 weeks ${ }^{\mathrm{a}}$

\begin{tabular}{|c|c|c|c|c|c|c|}
\hline Group & $\mathrm{n}$ & $\begin{array}{l}\text { Caecum content } \\
\text { (g) }\end{array}$ & Caecal pH & $\begin{array}{c}\text { Caecum SCFA } \\
\text { content } \\
(\mu \text { moles }) \\
\end{array}$ & $\begin{array}{c}\text { GUS } \\
\text { (U/g caecal content })\end{array}$ & $\begin{array}{c}\text { BGL } \\
\text { (U/g caecal content) }\end{array}$ \\
\hline Control & 10 & $1.90 \pm 0.34$ & $7.04 \pm 0.41$ & $125 \pm 44$ & $6.83 \pm 2.22$ & $8.20 \pm 3.35$ \\
\hline $2.1 \%$ pomace (-seeds) & 10 & $1.91 \pm 0.48$ & $6.87 \pm 0.17$ & $165 \pm 58$ & $6.56 \pm 2.40$ & $8.81 \pm 2.04$ \\
\hline $2.1 \%$ pomace $(+$ seeds $)$ & 10 & $1.79 \pm 0.46$ & $6.67 \pm 0.28$ & $150 \pm 39$ & $7.03 \pm 2.11$ & $11.11 \pm 2.81$ \\
\hline $2.1 \%$ pomace (both groups) & 20 & $1.85 \pm 0.46$ & $6.77 \pm 0.25$ & $158 \pm 42$ & $6.79 \pm 2.22$ & $9.96 \pm 2.67$ \\
\hline $6.5 \%$ pomace $(-$ seeds $)$ & 10 & $2.25 \pm 0.35$ & $6.76 \pm 0.19$ & $201^{\mathrm{b}} \pm 50$ & $7.82 \pm 2.50$ & $9.29 \pm 1.99$ \\
\hline $6.5 \%$ pomace $(+$ seeds $)$ & 10 & $2.51^{\mathrm{b}} \pm 0.52$ & $6.86 \pm 0.12$ & $194^{b} \pm 70$ & $8.42 \pm 5.27$ & $9.00 \pm 1.56$ \\
\hline $6.5 \%$ pomace (both groups) & 20 & $2.38^{\mathrm{b}} \pm 0.45$ & $6.81 \pm 0.16$ & $198^{\mathrm{b}} \pm 59$ & $8.12 \pm 4.03$ & $9.14 \pm 1.74$ \\
\hline
\end{tabular}

${ }^{\mathrm{a}}$ Data are presented as mean and SD

${ }^{\mathrm{b}}$ Statistically significantly different from control $(\mathrm{P}<0.05)$ (ANOVA)

SCFA short chain fatty acid, GUS $\beta$-glucuronidase, BGL $\beta$-glucosidase 
Table 5 Plasma lipids in rats fed control diet, or control diet added $2.1 \%$ or $6.5 \%$ apple pomace for 4 weeks $^{\mathrm{a}}$

\begin{tabular}{|c|c|c|c|c|c|c|}
\hline Group & $\mathrm{n}$ & $\begin{array}{c}\text { Total cholesterol } \\
(\mathrm{mmol} / \mathrm{L})\end{array}$ & $\begin{array}{c}\text { HDL-cholesterol } \\
(\mathrm{mmol} / \mathrm{L})\end{array}$ & $\begin{array}{c}\text { LDL-cholesterol } \\
(\mathrm{mmol} / \mathrm{L})\end{array}$ & $\begin{array}{c}\text { IDL-cholesterol } \\
(\mathrm{mmol} / \mathrm{L})\end{array}$ & $\begin{array}{c}\text { VLDL-cholesterol } \\
(\mathrm{mmol} / \mathrm{L})\end{array}$ \\
\hline Control & 10 & $1.28 \pm 0.10$ & $0.52 \pm 0.09$ & $0.24 \pm 0.08$ & $0.16 \pm 0.06$ & $0.10 \pm 0.03$ \\
\hline $2.1 \%$ pomace (-seeds) & 10 & $1.10 \pm 0.17$ & $0.43 \pm 0.09$ & $0.20 \pm 0.08$ & $0.13 \pm 0.07$ & $0.12 \pm 0.04$ \\
\hline $2.1 \%$ pomace $(+$ seeds $)$ & 10 & $1.05 \pm 0.11$ & $0.45 \pm 0.05$ & $0.20 \pm 0.04$ & $0.10 \pm 0.03$ & $0.09 \pm 0.02$ \\
\hline $2.1 \%$ pomace (both groups) & 20 & $1.07^{* *} \pm 0.14$ & $0.44 \pm 0.07$ & $0.20 \pm 0.06$ & $0.11^{*} \pm 0.05$ & $0.11 \pm 0.04$ \\
\hline $6.5 \%$ pomace (-seeds) & 10 & $1.09 \pm 0.13$ & $0.49 \pm 0.09$ & $0.17 \pm 0.03$ & $0.10 \pm 0.02$ & $0.12 \pm 0.03$ \\
\hline $6.5 \%$ pomace $(+$ seeds $)$ & 10 & $1.04 \pm 0.11$ & $0.48 \pm 0.08$ & $0.17 \pm 0.04$ & $0.10 \pm 0.04$ & $0.11 \pm 0.03$ \\
\hline $6.5 \%$ pomace (both groups) & 20 & $1.06^{* *} \pm 0.12$ & $0.49 \pm 0.08$ & $0.17^{* *} \pm 0.04$ & $0.10^{* *} \pm 0.03$ & $0.11 \pm 0.03$ \\
\hline
\end{tabular}

${ }^{\mathrm{a}}$ Data are presented as mean $\pm \mathrm{SD}$

significantly different from control (ANOVA), ${ }^{*} \mathrm{P}<0.05,{ }^{* *} \mathrm{P}<0.01$

$H D L$ high-density lipoprotein, $L D L$ low-density lipoprotein, $I D L$ intermediary-density lipoprotein, $V L D L$ very-low-density lipoprotein 
Table 6 Plasma antioxidant activity in rats fed control diet, or control diet added $2.1 \%$ or $6.5 \%$ apple pomace for 4 weeks $^{\mathrm{a}}$

\begin{tabular}{lcccc}
\hline Group & $\mathrm{n}$ & $\begin{array}{c}\text { FRAP } \\
(\mu \mathrm{mol} / \mathrm{L})\end{array}$ & $\mathrm{n}$ & $\begin{array}{c}\text { TEAC } \\
(\mathrm{mmol} / \mathrm{L})\end{array}$ \\
\hline Control & 10 & $841 \pm 151$ & 10 & $0.47 \pm 0.24$ \\
\hline $2.1 \%$ pomace (-seeds) & 10 & $753 \pm 122$ & 9 & $0.37 \pm 0.11$ \\
$2.1 \%$ pomace (+seeds) & 10 & $637^{\mathrm{c}} \pm 66$ & 9 & $0.27 \pm 0.27$ \\
\hline $2.1 \%$ pomace (both groups) & 20 & $695 \pm 113$ & 18 & $0.32 \pm 0.21$ \\
\hline $6.5 \%$ pomace (-seeds) & 10 & $768 \pm 174$ & 9 & $0.23 \pm 0.14$ \\
$6.5 \%$ pomace (+seeds) & 10 & $689^{\mathrm{b}} \pm 140$ & 8 & $0.46 \pm 0.59$ \\
\hline $6.5 \%$ pomace (both groups) & 20 & $729 \pm 159$ & 17 & $0.34 \pm 0.43$ \\
\hline
\end{tabular}

${ }^{\mathrm{a}}$ Data are presented as mean and SD

Statistically significantly different from control (ANOVA), ${ }^{b} \mathrm{P}<0.05,{ }^{\mathrm{c}} \mathrm{P}<0.01$

FRAP ferric reducing ability of plasma, TEAC trolox equivalent antioxidant capacity 
Figure 1 Concentrations of the SCFAs acetate, propionate and butyrate in caecal content of rats fed control diet or control diet containing $2.1 \%$ or $6.5 \%$ apple pomace for 4 weeks ${ }^{\mathrm{a}}$.

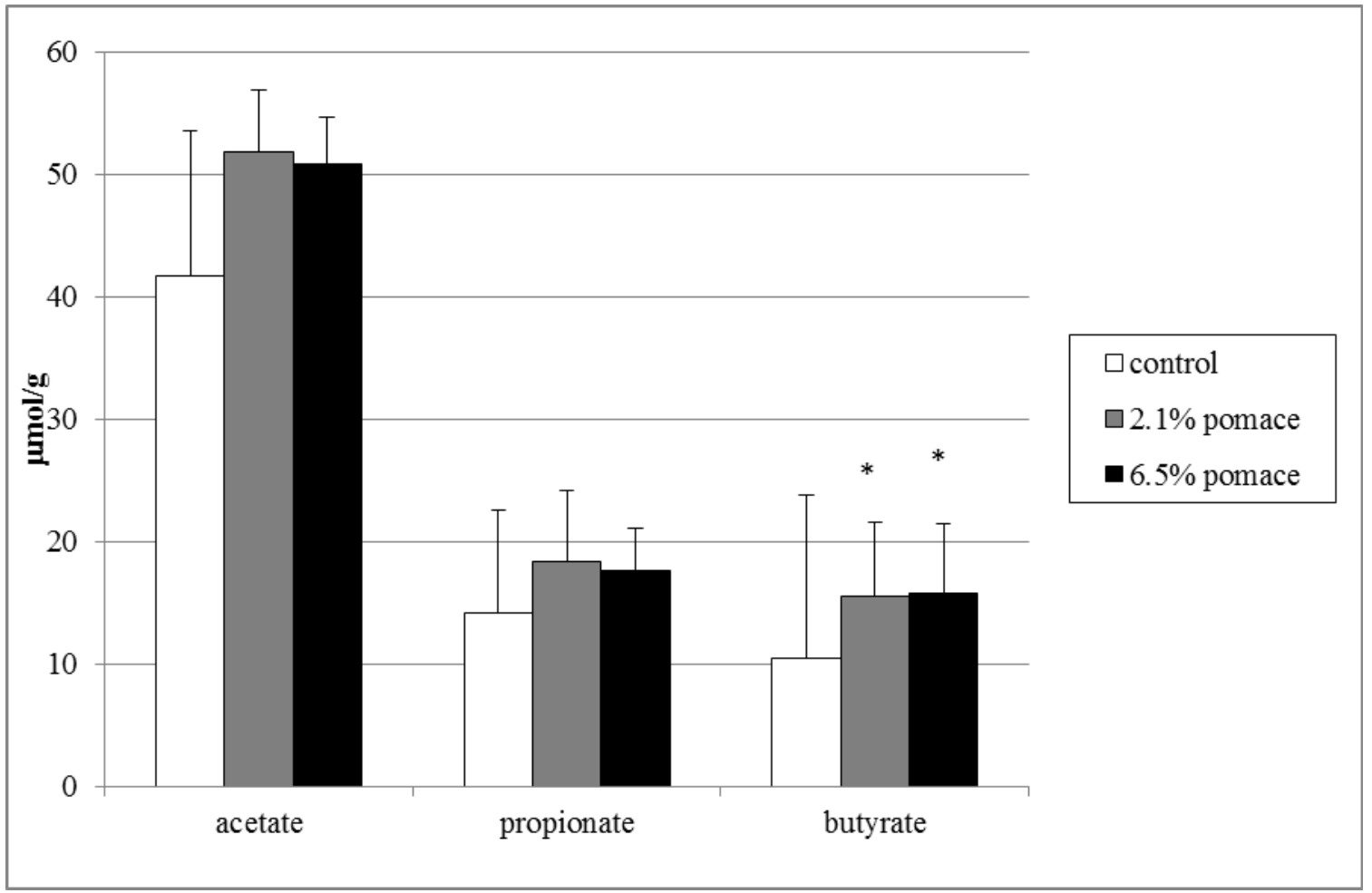

${ }^{\mathrm{a}}$ Data are presented in $\mu$ moles/g caecal content as mean and SD.

${ }^{*} \mathrm{P}<0.05$ (ANOVA). 
Figure 224 hrs faecal excretion of total-, primary- and secondary bile acids (BA) from rats fed control diet, or control diet added $2.1 \%$ or $6.5 \%$ apple pomace for 4 weeks $^{\mathrm{a}}$

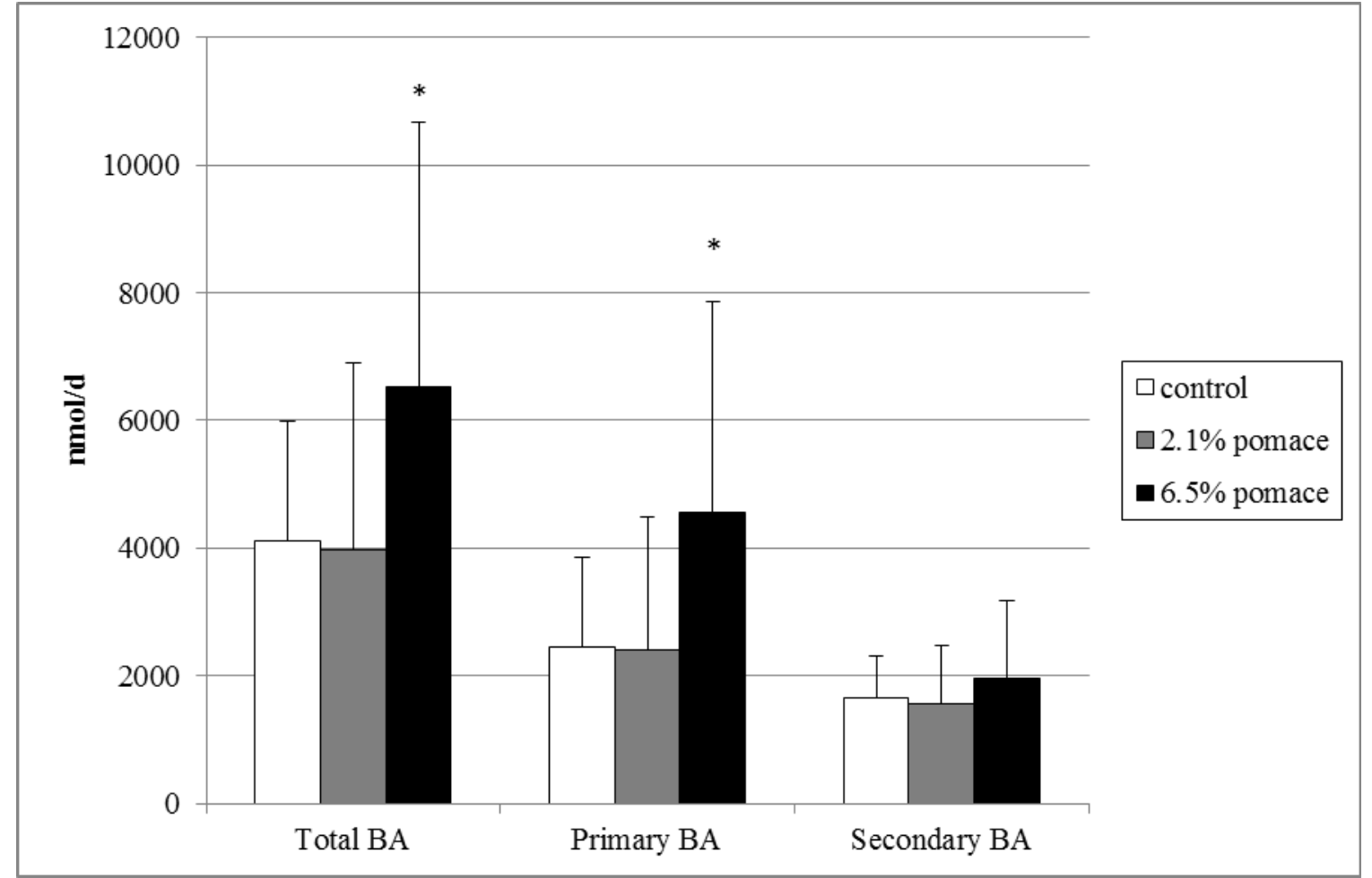

${ }^{\mathrm{a}}$ Data are presented in nmoles/d as mean and SD

$* \mathrm{P}<0.05$ compared to control and lowest dosage group (ANOVA)

$B A$ bile acids 
Figure 3 Concentration of total-, primary- and secondary bile acids (BA) in faecal samples from rats fed control diet, or control diet added $2.1 \%$ or $6.5 \%$ apple pomace for 4 weeks ${ }^{\mathrm{a}}$

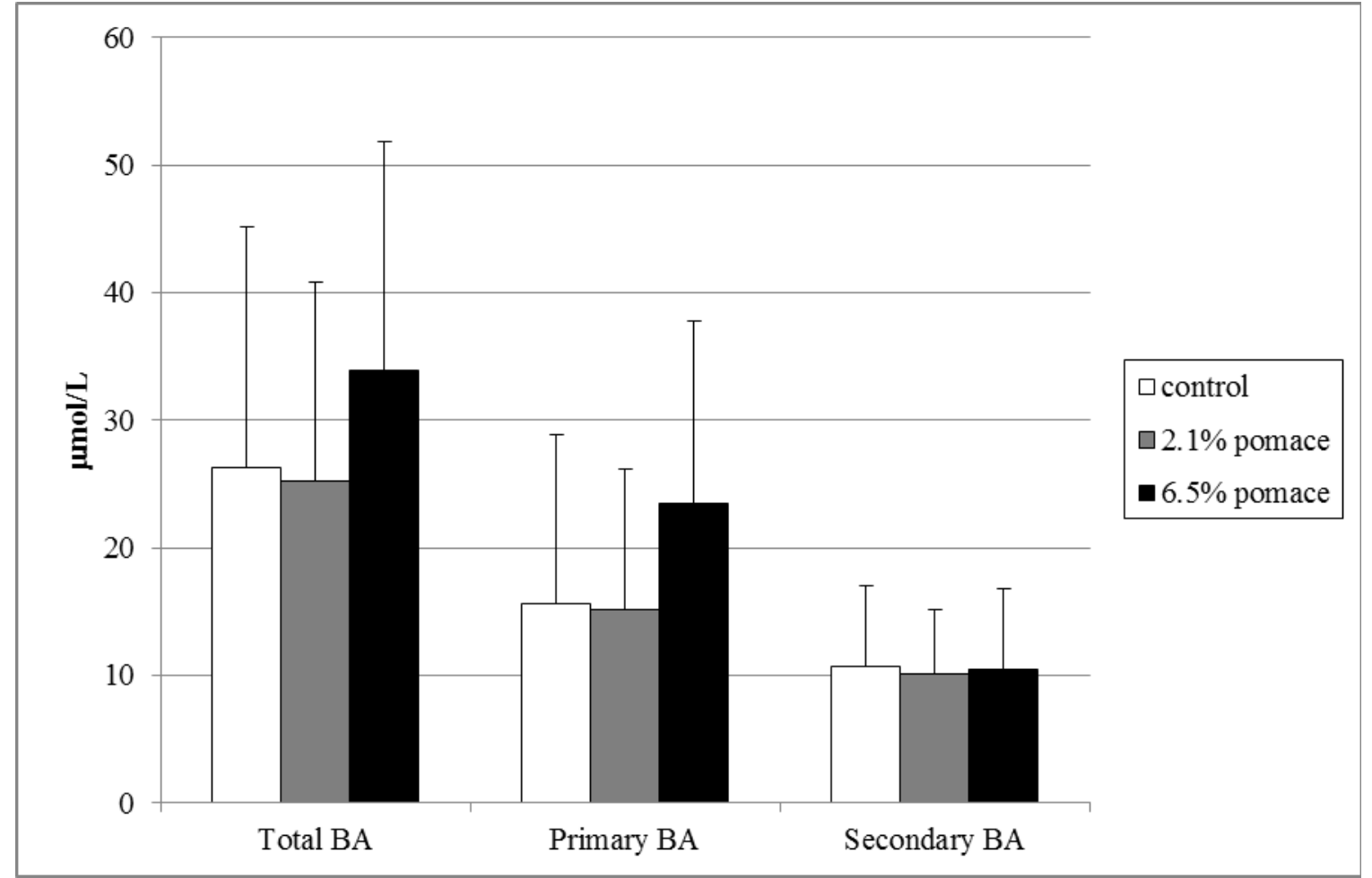

${ }^{\mathrm{a}}$ Data are presented in $\mu$ moles/L faeces as mean and SD

(ANOVA)

$B A$ bile acids 
Figure 4 Gene expression of Hmgcr and Cyp7a1 in blood, liver or colon of rats fed control diet, or control diet added $2.1 \%$ or $6.5 \%$ apple pomace without seeds for 4 weeks ${ }^{a}$

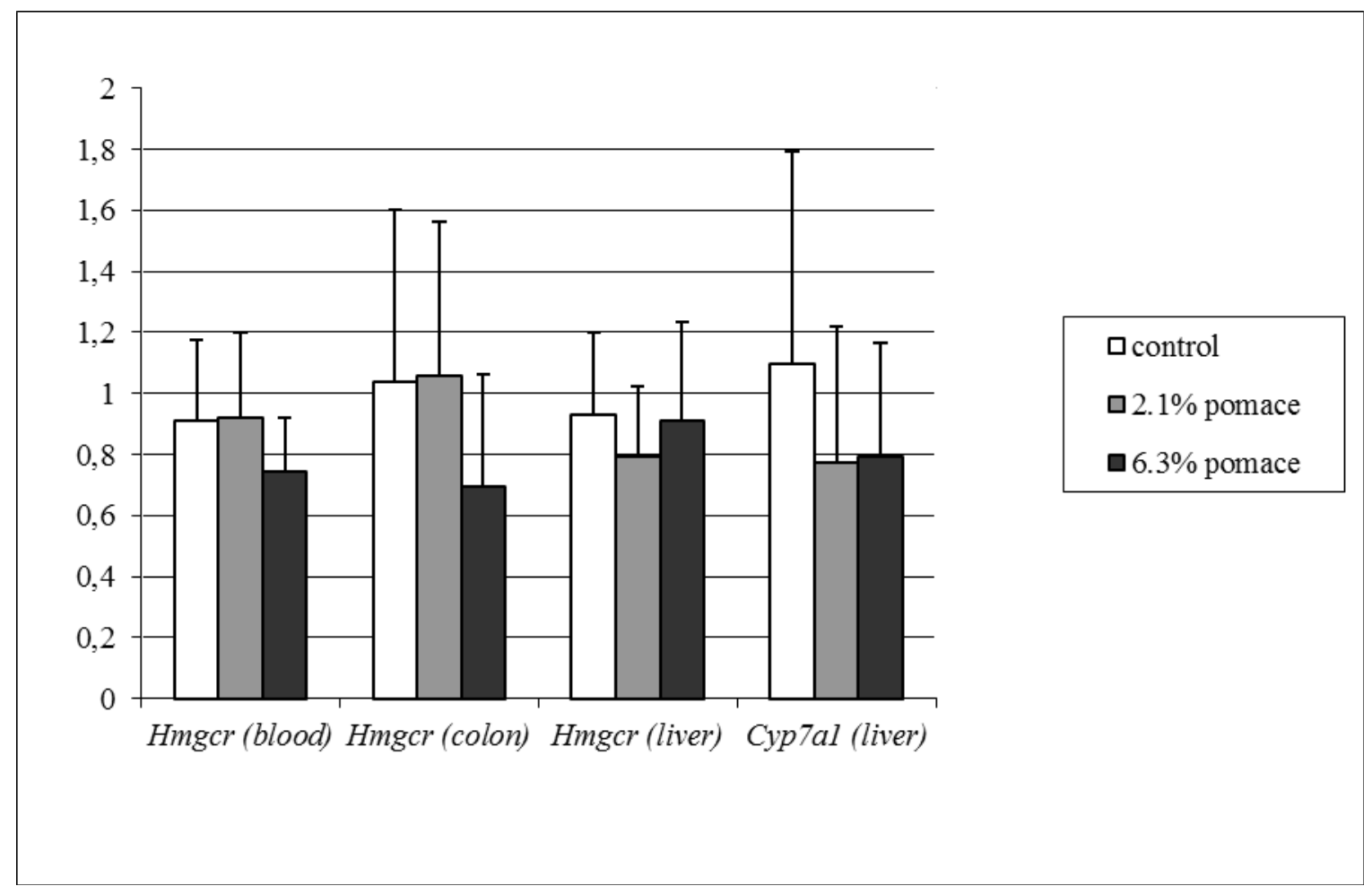

${ }^{\mathrm{a}}$ Data are presented as fold difference in gene expression relative to a calibrator as mean and $\mathrm{SD}$ ( $\mathrm{n}=8$ per group) (ANOVA)

HMGCR HMG-CoA reductase, CYP7A1 7 $\alpha$-hydroxylase 